\title{
STRATEGI PENGEMBANGAN PARIWISATA UNTUK PENINGKATAN PERTUMBUHAN EKONOMI DI KABUPATEN LOMBOK TIMUR
}

\author{
Oleh \\ Ahmad Suhendri ${ }^{1)}$ \& Muhammad Habibullah Aminy ${ }^{2)}$ \\ 1,2 Universitas Islam Al-Azhar \\ Email: ${ }^{1}$ hendrife@yahoo.com \& ${ }^{2}$ habibamin22@gmail.com
}

\begin{abstract}
This study is entitled Tourism Development Strategies for Increasing Economic Growth in East Lombok Regency. The object of this research is the tourism sector in East Lombok Regency in order to increase economic growth. Meanwhile, the problem examined in this study is the ways to increase the role of the tourism sector in East Lombok Regency paving the way to boost the economic growth. The method used in this study is qualitative through descriptive approach while the selected tool is SWOT analysis. The results of this study shows that the tourism sector in East Lombok Regency is in quadrant I or lies between external opportunities and positive internal forces (growth strategies) with rapid growth strategies which are the strategies that must be used to increase and maximize outputs from the tourism sector. This is to continue to grow so that later it will become a potential leading sector in East Lombok Regency.
\end{abstract}

Keywords: SWOT Analysis, Tourism Sector \& East Lombok

\section{PENDAHULUAN}

Pembangunan Kepariwisataan daerah merupakan rangkaian upaya pembangunan integrative dengan semua sector pendukung yang dilaksanakan secara sistematis dan berkesinambungan, dengan tujuan meningkatkan kesejahteraan masyarakat dan menambah pendapatan daerah. Pembangunan Pariwisata di Pulau Lombok dilaksanakan dalam mendorong dan meningkatkan pertumbuhan dan pemerataan ekonomi. Pariwisata merupakan industri kunjungan yang memiliki dampak multiflier effect yang sangat tinggi. Pariwisata mengundang berbagai pengunjung baik dalam (domestic) maupun dari luar negeri. Pengunjung yang datang baik untuk berlibur maupun yang lain akan mengeluarkan berbagai pembiayaan untuk memenuhi berbagai kebutuhannya selama berada didaerah tersebut.

Pulau Lombok merupakan salah satu Daerah Tujuan wisata (DTW) di Indonesia, yang merupakan bagian dari propinsi Nusa tenggara Barat. Potensi pariwisata yang dimiliki oleh Pulau Lombok merupakan salah satu usaha dalam rangka menggali sumberhttp://ejurnal.binawakya.or.id/index.php/MBI sumber pendapatan daerah yang bertujuan untuk meningkatkan kesejahteraan masyarakat, Pemerintah Daerah menempatkan sector Pariwisata sebagai sector andalan kedua setelah sector Pertanian dalam arti luas. Sebagai salah satu daerah tujuan wisata Pulau Lombok mempunyai potensi besar untuk dikembangkan. Potensi wisata yang dimiliki oleh Pulau Lombok adalah wisata budaya dan alamnya yang sangat mendukung pengembangan pembangunan pariwisata di Lombok. Sebagai keadaan alamnya yang masih asli merupakan daya terik tersendiri bagi wisatawan yang datang

Di sektor pariwisata Lombok Timur terkenal dengan berbagai potensi pariwisatanya, obyek wisata di Kabupaten Lombok Timur berupa pantai, gili, air terjun, dan pemandiannya, serta banyak lagi pemandangan-pemandangan yang indah. Dengan kekayaannya yang melimpah di sektor pariwisata Lombok Timur seharusnya bisa menjadi kabupaten yang terbaik di Provinsi Nusa Tenggara Barat. Namun pada kenyataanya Lombok Timur seperti macan terpuruk, yang memiliki potensi luar biasa tapi

Vol.14 No.4 Nopember 2019 
belum di manfaatkan secara maksimal sehingga membuat perekonomian penduduk Lombok Timur masih jauh dari harapan.

Permasalahan dalam Penelitian

1. apakah Permasalahan yang dihadpi oleh sektor pariwisata di Kabupaten Lombok Timur?

2. Bagaimanakah perumusan starategi penegembangan sektor pariwisata di Kabupaten Lombok Timur guna meningkatkan pertumbuhan ekonomi?

Tujuan Khusus

1. Melakauakan identifikasi permasalahan sektor pariwisata yang ada di Kabupaten Lombok Timur

2. Untuk menentukan strategi pengembangan sektor pariwisata di kabupaten Lombok Timur

\section{LANDASAN TEORI}

Penelitian yang dilakukan oleh Sholehatun 2010, dengan judul Strategi Komunikasi Pemasaran Terpadu (IntegratedMarketing Communications) Dalam Mengokohkan Brand Dagadu Djokdja, dengan responden atau narasumber Konsumen dagagu djokdja, Metode penelitian ini menggunakan pendekatan kualitatif. Sedangkan tipe penelitian ini menggunakan tipe deskripsi kualitatif, Hasil penelitian menunjukkan adanya keberhasilan yang cukup memuaskan. Hal ini dapat dilihat dari peningkatan junlah konsumen yang ada pada tingkatan kesukaan, kepuasan dan kepercayaan terhadap PT. ADD, meskipun belum sepenuhnya terlaksana denganbaik.

Penelitian yang dilakukan oleh Andrianto 2010, dengan judul Strategi Komunikasi Pemasaran Event Budaya SIEM (Solo Internasional Contemporary Ethnic Music) 2010 dalam Menarik Minat Pengunjung, dengan responden Masyarakat Kota solo khususnya pecinta musik, metode yang digunakan Penelitian deskriptif pendekatan kualitatif, hasil penelitian SIEM 2010 dalam kegiatan menarik minat pengunjung melakukan strategi komunikasi pemasaran sesuai dengan langkahlangkah yang dijalankan. SEIM 2010menggunakan empat

\section{Vol.14 No.4 Nopember 2019}

bauran promosi yaitu periklanan, hubungan masyarakat, penjualan tatap muka dan pemasaran langsung. Setelah menentukan bauran promosi, langkah selanjutnya adalah mengukur hasil promosi, caranya yaitu dengan menghitung jumlah tiket yang sudah tersebar.

Penelitian yang dilakukan oleh Puji Wahono dkk 2017, dengan judul Prospek Ekonomi Pengembangan Potensi Lokal Dalam Mendukung pengelolaan wisata Di Wilayah Sekitar Gunung Bromo, metode penelitian yang digunakan adalah deskriptif kualitatif dengan teknik pengumpulan data wawancara, observasi, dokumentasi, dan untuk mendapatkan, Hasil Penelitian ini menunjukkan Adapun strategi yang berbasis masyarakat akan lebih tepat untuk pengembangan destinasi wisata di sekitar kawasan Bromo tersebut. Penelitian ini dilakukan di empat kabupaten sekitar kawasan Taman Nasional Gunung Bromo yakni Kabupaten Malang, Pasurauan, Probolinggo, dan Lumajang.

Teori Pembangunan dan Pertumbuhan Ekonomi Daerah

Menurut Arsyad (2010), pembangunan ekonomi daerah adalah suatu proses, yaitu proses yang mencakup pembentukan institusi-institusi baru, pembangunan industri-industri alternatif, dimana pemerintah daerah dan masyarakat mengelola sumber daya yang ada dan membentuk suatu pola kemitraan antara daerah dengan sektor swasta. Masalah pokok dalam pembangunan daerah terletak pada penekanannya terhadap kebijakan-kebijakan pembangunan yang didasarkan pada ciri khas (unique value) dari daerah yang bersangkutan dengan menggunakan potensi sumber daya manusia, kelembagaan, dan sumber daya fisik secara lokal (daerah). Ada beberapa teori yang secara parsial dapat membantu untuk memahami arti penting pembangunan ekonomi daerah, yaitu teori Ekonomi Neo Klasik, teori Basis Ekonomi (Economic Base Theory).

Pertumbuhan ekonomi wilayah adalah pertambahan pendapatan masyarakat secara keseluruhan yang terjadi di wilayah tersebut, yaitu kenaikan seluruh nilai tambah (value added) yang terjadi (Tarigan, $2008: 46$ ).

http://ejurnal.binawakya.or.id/index.php/MBI 
jasa yang dihitung menggunakan harga pada

Perhitungan pendapatan wilayah pada awalnya dibuat dalam harga berlaku. Namun agar dapat melihat pertambahan dari satu kurun waktu ke kurun waktu berikutnya, harus dinyatakan dalam nilai riel, artinya dinyatakan dalam harga konstan. Pendapatan wilayah menggambarkan balas jasa bagi faktor-faktor produksi yang beroperasi di daerah tersebut (tanah, modal, tenaga kerja, dan teknologi), yang berarti secara kasar dapat menggambarkan kemakmuran daerah tersebut. Kemakmuran suatu wilayah selain ditentukan oleh besarnya nilai tambah yang tercipta di wilayah tersebut juga oleh seberapa besar terjadi transfer payment, yaitu bagian pendapatan yang mengalir ke luar wilayah atau mendapat aliran dana dari luar wilayah

\section{Teori Tentang Peroduk Domestik Regional Bruto}

Untuk mengukur seberapa besar kinerja perekonomian suatu wilayah disuatu negara maka dapat dilihat dari kontribusi produk domestic regional bruto (PDRB) terhadap pembentukan produk domestic bruto (PDB) total nasional. Produk domestic regional bruto merupakan salah satu indicator ekonomi makro yang berperan dalam membuat perencanaan kebijakan dalam pembangunan, menentukan arah pembangunan serta mengevaluasi hasil pembangunan wilayah tersebut. PDRB dapat diartikan sebagai suatu indikator untuk menunjukkan laju pertumbuhan ekonomi suatu daerah secara sektoral, sehingga dapat dilihat penyebab pertumbuhan ekonomi suatu wilayah tersebut (Novrilasari,2008).

Semakin tinggi nilai PDRB perkapita berarti semakin tinggi kekayaan daerah. PDRB merupakan jumlah nilai tambah atau jumlah ilai barang dan jasa akhir yang dihasilkan oleh seluruh unit usaha dalam suatu daerah dalam satu tahun. PDRB atas dasar harga berlaku menggambarkan nilai tambah barang dan jasa yang dihitung dengan menggunakan harga pada tahun tersebut, digunakan untuk melihat pergeseran struktur ekonomi, sedangkan PDRB atas dasar harga konstan menunjukkan nilai tambah barrang dan http://ejurnal.binawakya.or.id/index.php/MBI tahun tertentu sebagai dasar. PDRB atas dasar harga konstan digunakan untuk mengetahui pertumbuhan ekonomi dari tahun ke tahun. Untuk menghitung PDRB digunakan 3 pendekatan (sukirno,) sebagai berikut:

1. ditinjau dari sisi produksi regional merupakan jumlah nilai tambah (produksi) yang dihasilkan oleh unitunit produksi yang dimiliki penduduk suatu daerah dalam jangka waktu tertentu.

2. ditinjau dari sisi pendapatan regional merupakan jumlah nilai tambah (produksi) yang dihasilkan oleh unitunit produksi yang dimiliki penduduk suatu daerah dalam jangka waktu tertentu.

3. Ditinjau dari segi pengeluaran regional merupakan jumlah pengeluaran konsumsi atau komponen permintaan akhir yang dilakukan oleh rumah tangga, lembaga swasta, pemerintah dengan pembentukan modal domestic bruto, perubahan stok dan ekspor neto suatu daerah dalam jangka waktu tertentu.

\section{Teori Pariwisata}

Pariwisata sebagai suatu industri sangat luas cakupannya. Pariwisata adalah salah satu jenis industri baru yang mampu menghasilkan pertumbuhan ekonomi yang cepat dalam penyediaan lapangan kerja, peningkatan penghasilan, standar hidup serta menstimulasi sektor- sektor produktivitas lainnya. Hingga saat ini cukup banyak batasan yang diberikan beberapa pakar tentang pariwisata. Macintosh (dikutip Oka A. Yoeti, 2006:48) mengatakan bahwa pariwisata adalah sejumlah gejala dan hubungan yang timbul, mulai dari interaksi antara wisatawan di satu pihak, perusahaanperusahaan yang memberikan pelayanan kepada wisatawan dan pemerintah serta masyarakat yang bertindak sebagai tuan rumah dalam proses menarik dan melayani wisatawan dimaksud.

\section{Vol.14 No.4 Nopember 2019}




\section{METODE PENELITIAN}

\section{Jenis Penelitian}

Jenis penelitian ini adalah deskriptif dengan pendekatan metode kualitatif. Penelitian deskriptif merupakan suatu metode dalam meneliti status sekelompok manusia, suatu objek, suatu set kondisi, suatu sistem pemikiran ataupun suatu kelas peristiwa pada masa sekarang (Nazir,2014).

Dalam penelitian ini menjelaskan bagaimana cara perumusan strategi pengembangan sektor pariwisata di kabupaten lombok timur dengan analisis SWOT.

\section{Lokasi Penelitian}

Penelitian ini akan dilaksanakan di Kabupaten Lombok Timur. Kabupaten Lombok Timur merupakan salah satu Kabupaten yang mempunyai wilayah terluas di Pulau Lombok serta mempunyai jumlah penduduk yang besar dibandingkan Kabupaten/Kota lainnya. Lombok memiliki banyak potensi dibidang sektor ekonominya, tetapi masih belum dimaksimalkan seperti sektor pariwisata.

\section{Teknik Pengumpulan Data}

Teknik pengumpulan data dilakukan dengan metode observasi langsung, dokumentasi dan wawancara. Metode observasi yaitu cara pengambilan data secara langsung dengan menggunakan mata tanpa ada pertolongan alat standar lain untuk keperluan tersebut (Nazir,2014), sedangkan metode dokumentasi yaitu mengumpulkan data sekunder dari berbagai sumber berupa data kunjungan wisatawan baik domestik dan manca negara, sedangkan teknik wawancara adalah suatu bentuk komunikasi verbal, jadi semacam percakapan yang bertujuan memperoleh informasi (Nasution, 2004).

\section{Alat Analisis}

Adapun alat analisis yang digunakan dalam penelitian ini adalah teknik analisis SWOT, analisis ini merupakan bagaimana menguraikan mengenai (Strenghts, Weaknes, Oportunities, Thereat ), alat analisis yang digunakan unutk menentukan kekuatan, kelemahan, peluang serta ancaman yang ada pada sektor pariwisata tersebut. Dalam hal ini kekuatan serta kelemahan ini di tentukan oleh internal dari sektor pariwisata ini, sedangkan peluang dan ancaman ini merupakan lingkungan eksternal dari sektor pariwisata inia.

a. Lingkungan internal yang terdiri dari :

1.Kekuatan (strenghts) adalah situasi dan kemampuan internal yang bersifat positif yang mampu terus menjaga sektor pariwisata ini terus berkembang

2.Kelemahan (weaknes) adalah situasi dan faktor-faktor yang berasal dari dalam yang sifatnya negatif, yang nantinya akan menyebabkan pariwisata ini mengalami kelesuan

b. Lingkungan eksternal terdiri dari :

1.Peluang (oportunities) adalah situasi dan faktor-faktor yang akan menjadi peluang bagi sektor pariwisata tersebut terus berkembang yang nantinya akan mendongkrak pertumbuhan ekonomi di Kabupaten Lombok Timur

2.Ancaman (threats) adalah faktorfaktor dari luar yang akan dapat menyebabkan atau mengancam dari sektor pariwisata ini menjadi lesu

Atas dasar identifikasi dan analisis berbagai aspek di atas dapat digambarkan dalam matriks sebagai berikut

\begin{tabular}{|l|l|c|}
\hline \multicolumn{1}{|c|}{ ekstenal } & Strenghts & Weaknes \\
internal & & Strategi W-O \\
\hline Oportunities & Strategi S - O & Strategi W-T \\
\hline Threats & Strategi S - T & . \\
\hline
\end{tabular}

Dari matriks tersebut dapat dibaca sebagai berikut :

1. Strategi $\mathrm{S}-\mathrm{O}$ adalah strategi mengoptimalkan kekuatan untuk menafaatkan peluang yang ada

2. Strategi $\mathrm{W}-\mathrm{O}$ adalah strategi mengurangi kelemahan untuk memanfaatkan peluang yang ada

3. Strategi $\mathrm{S}-\mathrm{T}$ adalah strategi menggunakan kekuatan menggunakan kekuatan untuk mencegah dan mengatasi ancaman yang ada

4. Strategi $\mathrm{W}-\mathrm{T}$ adalah strategi untuk mengurangi kelemahan untuk

http://ejurnal.binawakya.or.id/index.php/MBI 
mencegah dan mengatasi ancaman yang ada.

\section{HASIL DAN PEMBAHASAN}

Terkait dengan potensi wisata yang ada di Kabupaten Lombok Timur ini, perlu dilakukan perumusan strategi yang tepat untuk penegelolaan potensi wisata ini guna memiliki value added yang tinggi sehingga tercipta pertumbuhan ekonomi yang mantap. Terkait dengan potensi wisata yang ada di Kabupaten Lombok Timur ini berikut potensi wisata yang ada di Kabupaten Lombok Timur:

1. Wisata Alam

a. Rinjani dan Segara Anak, Gunung Rinjani adalah Gunung yang berlokasi di Pulau Lombok, gunung rinjani ini merupakan gunung yan tetinggi kedua di Indonesia dengan ketinggian 3726 mdpl , Gunung Rinjani ini merupakan Gunung Favorit bagi para pendaki, karena gunug rinjani salah satu gunung yang lengkap, artinya dari segi pemandangan sangat bagus, dari segi tracking serta claimbing juga sangat memadai, bagi para pendaki sangat senag berkunjung ke Gunung Rinjani, dan gunung ini merupakan salah satu favorit bagi para pendaki.

b. Sembalun

Sembalun merupakan salah satu daerah kecamatan yang ada di Kabupaten Lombok Timur. Sembalun ini merupakan daerah dengan kondisi alam yang sanagt luar biasa, karena dari segi iklim serta alam sangat bagus sekali, daerah sembalun ini merupakan salah satu destinasi favorit untuk berwisata.

c. Air Terjun Mayung Puteq

Air terjun ini terdapat di desa Bilok Petung, kecamatan Sembalun kabupaten Lombok Timur yang merupakan luapan dari limpahan air hujan dari danau Segara Anak dan bagian dari hulu kokok Putek yang airnya berwarna putih

d. Air Terjun Dewi Selendang

Air terjun Dewi Selendang berada di daerah Sembalun, Kabupaten Lombok Timur, Kedalaman air terjun ini sekitar $50 \mathrm{~cm}$ sampai 3 meter. Berendam di air terjun ini akan membuat tubuh menjadi segar kembali.

e. Air Terjun Joben

Air terjun ini berada di Desa Montong Betok, Kecamatan Montong Gading, Lombok Timur, Nusa Tenggara Barat. Objek wisata ini memiliki ketinggian sekitar 5 meter, di mana air terjunnya keluar dari akar pohon banjur yang sudah berumur hingga ratusan tahun.

f. Air terjun Jeruk Manis

Aair Terjun Jeruk Manis berada di Desa Kembang Kuning, Kecamatan Sikur, Kabupaten Lombok Timur. Air terjun ini memiliki ketinggian sekitar 30 Meter, kemudian mengalir ke sungai kecil yang penuh dengan bebatuan.

2. Wisata Pantai

Kabupaten Lombok Timur memiliki banyak destinasi wisata pantai, ada bebrapa banmyak destinasi wisata pantai yang ada di Kabupaten Lombok Timur, dengan pemandanagan yang sangat menakjubkan. Adapun diantaranya adalah sebagai berikut :

a. Pantai Labuhan Haji

Terletak di bagian timur Kabupaten Lotim, sebagai bekas pelabuhan peninggalan zaman lampau, pantai Labuhan Haji sedikitnya juga meninggalkan sejarah dan sisa-sisa peradaban sebagai kota pelabuhan, di mana pusa pemerintahan Lombok Timur semasa di pimpin raja Selaparang berpusat di Labuhan Haji, pantai labuhan haji sangat indah sekali, dan terletak di Desa Labuhan

Vol.14 No.4 Nopember 2019 
Haji, Kecamatan Labuhan Haji Kabupaten Lombok Timur.

b. Pantai Pink

Pantai Pink Lombok ini berada di ujung timur Pulau Lombok, berdekatan dengan tempat wisata Tanjung Ringgit. Tepatnya pantai ini berlokasi di Desa Sekaroh, sebuah desa kecil di Kecamatan Jerowaru, Lombok Timur.

c. Pantai Cemara

Selain Pantai Cemare Lombok Barat, ada juga yang namanya Pantai Cemara di Lombok Timur, pantai ini berdekatan dengan pantai pink, dan berda di tanjung ringgit, Kabupaten Lombok Timur. Pantai Cemara Lombok ini terletak di sebuah teluk dengan posisi agak menjorok ke daratan. Jadi meskipun berlokasi di bagian selatan yang berbatasan langsung dengan samudra Hindia, Pantai Cemara Lombok cocok untuk berenang, dan ombaknya cukup tenang.

d. Pantai Kura-kura

Satu lagi anugerah terindah dari Tuhan yang diberikan kepada Lombok Timur (Lotim). Anugerah keindahan alam yang menawan itu ada di Pantai Kura-kura. Itulah nama pantai yang diberikan warga. Fanorama pantai yang eksotik ini memiliki daya tarik luar biasa bagi siapa saja yang berkunjung ke sana. Pantai yang terletak di Dusun Sungkun, Desa Ekas Buana, Kecamatan Jerowaru, Kabupaten Lombok Timur ini terlihat masih belum terjamah. Pantai yang berjarak sekitar $5 \mathrm{Km}$ dari jalan utama ini tidak banyak dikenal oleh masyarakat.

e. Pantai Tanjung Bloam

Pantai Tanjung Bloam terletak di wilayah Jerowaru Kabupaten Lombok Timur. Tanjung Bloam lebih dikenal sebagai wilayah konservasi penyu

Vol.14 No.4 Nopember 2019 dengan habitatnya yang berada di sepanjang garis pantai yang memanjang dari ujung selatan sampai ujung utara. Selain penyu, Pantai Tanjung Bloam memiliki keindahan alam yang begitu alami dan hampir terlupakan oleh para wisatawan. Begitu tiba di pantai ini, anda akan disuguhkan dengan hamparan pasir putih yang begitu lembut dan air laut yang jernih membiru.

f. Pantai Surga

Pantai surga ini memang terletak di daerah yang cukup terpencil, dan cukup jauh, namun pantai ini menyimpan pesona yang tak kalah dari pantai - pantai lainnya di Lombok, Pantai yang terbentang sepanjang 600 meter ini di apit oleh dua tebing yang cukup tinggi. Tebing - tebing tersebut di selimuti oleh pohon sehingga membuatnya kehijauan dan mengapit pantai yang berbentuk huruf $\mathrm{U}$.

3. Wisata Gili

Selain wisata alam, wisata pantai, Kabupaten Lombok Timur juga memiliki beberapa destinasi wisata gili, adapun gili-gili yang terdapat di Kabupaten Lombok Timur diantaranya adalah :

a. Gili Beleq

Nama Gili Beleq berasal dari bahasa lombok atau bahasa sasak yang berarti Pulau Besar jika diterjemahkan ke dalam bahasa Indonesia, Gili Beleq merupakan salah satu pulau kecil yang terletak di Kecamatan Jerowaru, Kabupaten Lombok Timur, Propinsi Nusa Tenggara Barat dengan luas wilayah sekitar $8 \mathrm{Ha}$.

b. Gili Bembek

Gili Bembeq, sebuah Gili (pulau kecil) yang tak berpenghuni yang berada di kecamatan Tanjung Luar, kabupaten Lombok Timur, Bembeq sendiri berarti kambing dalam bahasa sasak. 
c. Gili Sunut

Gili Sunut, terletak di Desa Pemongkong, Kecamatan Jerowaru. Dalam hal wilayah administrasi, Gili Sunut masih bagian dari Kabupaten Lombok Timur. Gili Sunut menjadi alternatif yang baik bagi Gili lainnya karena menawarkan keindahan dan ketenangan yang serupa.

d. Gili Kondo

Terletak di Kecamatan Sambelia, Lombok Timur, Nusa Tenggara Barat, Gili Kondo merupakan satu dari beberapa pulau kecil atau gili di timur Pulau Lombok. Gili ini berdampingan dengan Gili Bidara, dan dekat dengan Gili Lampu dan Gili Kapal. Gili Kondo relatif belum terkenal dibanding Pantai Senggigi, Gili Trawangan, Gili Air dan gili-gili (pulau kecil) lainnya di Pulau Lombok. Tak heran, jika gili ini sepi dari pengunjung dan masih perawan. Kalau pun ada pengunjung, hanya warga lokal dan beberapa wisatawan mancanegara saja.

e. Gili Lawang

Hampir semua wisatawan mengetahui keindahan Taman Nasional Gunung Rinjani di Pulau Lombok. Taman ini terdiri dari berbagai obyek wisata alam bahkan beberapa pulau kecil atau yang lebih dikenal dengan Gili. Salah satunya disebut Pulau atau Gili Lawang dan merupakan bagian dari Kabupaten Lombok Timur.

4. Wisata Buatan

Disamping itu juga Lombok Timur juga memiliki keindahan wisata buatan, salah satu diantaranya adalah sebagai berikut :

a. Rinjani Waterpark

Rinjani Waterpark merupakan salah satu wisat buatan yang berlokasi di Rakam Kabupaten Lombok Timur. Sebuah waterpark berstandar nasional yang dibangun dengan konsep ecowater yang asri, berasal dari sumber mata air Rakam yang menyegarkan. Rinjani Waterpark sangat memperhatikan keamanan dan kenyamanan pengunjung.

b. Tirta Rinjani

Tirta Renjani, merupakan salah satu wisata buatan berupa kolam renag, wisata ini merupakan salh satu destinasi wisata yang sangat bagus dikunjungi untuk berenang. Lokasi dari Tirta renjani ini berada di Kota Selong Kabupaten Lombok Timur

c. Planet Garden Waterpark

Tempat ini merupakan wisata air yang ada di Kelurahan Kelayu Utara, Desa Kebun Tatar Kabupaten Lombok Timur, dan ini merupakan satusatunya yang ada di Kelayu Utara.

Lombok Timur memiliki banyak destinasi wisata yang sangat layak untuk dikunjungi. Terkait dengan keberadaan destinasi wisata di Kabupaten Lombok Timur ini masih tidak begitu banyak pengunjung, untuk itu perlu adanya strategi khusus untuk memajukan pariwisata di Kabupaten Lombok Timur, guna peningkatan pendapatan serta pertumbuhan ekonomi di Kabupaten Lombok Timur.

Terkait dengan strategi tersebut, maka peneliti merumusankan strategi pengembangan pariwisata di Kabupaten Lombok Timur berdasrkan analisis SWOT. Berdasrkan hasil observasi yang dilakukan oleh peneliti amaka rumusan SOWT ( Strenght, Oportunity, Weakness, dan Treat) terkait dengan penentuan strategi pariwisata di Kabupaten Lombok Timur.

1. Kekuatan (strengths) adalah situasi dan kemampuan internal yang bersifat positif, adapun dari kekuatan tersebut berdasarkan data-data yang diperoleh peneliti dari Observasi serta wawancar dengan Dinas Terkait adalah

a. Bnayaknya destinasi Wisata yang dengan pemandangan yang sangat luar biasa.

b. Wisata alam yang masih sangat alami dan asri.

Vol.14 No.4 Nopember 2019 
c. Keramahan dari para penduduk lokal

d. Kondisi jalan di kabupaten Lombok Timur yang sudah mulai membaik.

2. Kelemahan (weakness) adalah situasi dan fakror-faktor yang berasal dari dalam yang sifatnya negatif. Terkait dengan kelemahan yang ada pada daerah wisata di Kabupaten Lombok Timur adalah sebagai berikut :

a. Masih belum terlalalu memadainya akses ke lokasi wisata seperti jalan dan sebagainya

b. Belum tersedianya fasilitas fasilitas wisata, seperti hotel yang memadai seperti hotel bintang lima.

c. Kurangnya peromosi terhadap tempat-tempat wisata yang ada di kabupaten Lombok Timur

d. Kemampuan dari pengelolaan wisata yang ada di Kabupaten Lombok Timur masih belum memadai (masih bersifat lokal)

e. Kemampuan dari SDM untuk pengelolaan masih tidak begitu mumpuni

Faktor-faktor eksternal :

1. Peluang (opportunities) merupakan situasi dan faktor-faktor yang akan menjadi peluang bagi sector pariwisata di Kabupaten Lombok Timur tersebut tersu berkembang, diantaranya :

a. Masyrakat luar sudah mulai mengenal Lombok Timur Sebagai salah satu destinasi wisata favorit

b. sudah mulai gaungnya Lombok sebagai destinasi wisata halal

c. susdah mulainya tingkat dukungan dari pemerintah daerah setempat.

2. Ancaman (threats) merupakan faktorfaktor dari luar yang menyebabkan sector pariwisata ini untuk tidak berkembang adalah sebagai berikut:

a. Kabupaten-kabupaten atau wilayah lain, yang memiliki potensi wisata yang sama, seperti Lombok Barat, Lombok Utara, serta pulau lain seperti Bali.

b. Banyaknya berbagai isu-isu yang menyebar luas di sosial media mengeani gempa, sehingga pengunjung enggan datang.

Setelah melakukan analisis kondisi internal dan eksternal, selanjutnya akan dilakukan perhitungan bobot faktor internal dan eksternal guna mengetahui letak kuadran strategis pengembangan yang dianggap mendesak untuk dilakukan. Perhitungan bobot faktor tersebut dilakukan dengan membuat tabulasi IFAS-EFAS (Internal-Eksternal Strategic Factor Analysys Summary). Berikut adalah perhitungan bobot faktor internal dan eksternal yang tertuang dalam dalam tabel analisis IFAS dan EFAS yang diperlihatkan pada tabel dibawah ini

\section{Tabel 1. Analisis Faktor Strategis Internal} IFAS Sektor Pariwisata

\begin{tabular}{|c|c|c|c|c|c|}
\hline \multirow{5}{*}{$\frac{\text { No }}{I}$} & Faktor-fakhtor strategis & Bobot & Ranting & Score & Komentar \\
\hline & 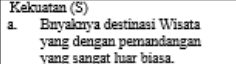 & 0,15 & 4 & 0,60 & $\begin{array}{lll}\text { Kuantitas destinasi } & \text { wissta } \\
\text { adalah } & \text { kunci } & \text { sulkses } \\
\text { pengembangan }\end{array}$ \\
\hline & $\begin{array}{l}\text { b. Wisata alam yang masih sangat } \\
\text { alami dan asri. }\end{array}$ & 0,10 & 3 & 0,30 & $\begin{array}{l}\text { Kondiai yang mendukihmg } \\
\text { minat kunjungan tisstwan }\end{array}$ \\
\hline & $\begin{array}{l}\text { c. Keramahan dari para penduduk } \\
\text { lokal }\end{array}$ & 0,10 & 3 & 0,30 & $\begin{array}{l}\text { Salah satu daya tarik wisstatuan } \\
\text { dalam kenymananan melahakanan } \\
\text { humjungagn wisata }\end{array}$ \\
\hline & $\begin{array}{l}\text { d. Kondisi jalan di kabupaten } \\
\text { Lombok Timur yang sudah } \\
\text { mulai membaik }\end{array}$ & 0,15 & 3 & 0,45 & $\begin{array}{l}\text { Salah satu faktor pendorong } \\
\text { untuk kemajuan parivisata }\end{array}$ \\
\hline \multirow[t]{6}{*}{ II } & $\begin{array}{l}\text { Kelemahan (W) } \\
\text { a. Masih belum terlalalu } \\
\text { memadainya akses ke lokasi } \\
\text { wisata seperti jalan dan } \\
\text { sebagainya }\end{array}$ & 0,10 & 2 & 0,20 & $\begin{array}{l}\text { Penyebab penturunan minat } \\
\text { untuk hunjungan wisata }\end{array}$ \\
\hline & $\begin{array}{l}\text { b. Belum tersedianya fasilitas - } \\
\text { fasilitas uisasta, seperth hotel yang } \\
\text { memadai seperti hotel bintang } \\
\text { lima. }\end{array}$ & 0,05 & 3 & 0,15 & $\begin{array}{l}\text { Tidak memaksimalikan } \\
\text { pendapatan seltor parivisata }\end{array}$ \\
\hline & $\begin{array}{l}\text { c. Kuranganya peromosi terhadap } \\
\text { tempat-tempat wisata yang ada di } \\
\text { kabupaten Lombok Timur }\end{array}$ & 0,15 & 1 & 0,15 & $\begin{array}{l}\text { Hal yang mempengaruhi } \\
\text { kurang dikenalay destinasi } \\
\text { uvisata yang ada }\end{array}$ \\
\hline & $\begin{array}{l}\text { d. Kemampuan dari pengelolaan } \\
\text { wisata yang ada di Kabupaten } \\
\text { Lombok Timur mash belum } \\
\text { memadai (masih bersifat lokal) }\end{array}$ & 0,10 & 1 & 0,10 & $\begin{array}{l}\text { Dapat menyebablan tumpang } \\
\text { tindihnya kebijakan }\end{array}$ \\
\hline & $\begin{array}{l}\text { f. Kemampuan dari SDM untulk } \\
\text { pengelolaan masih tidak begitu } \\
\text { mumpuni }\end{array}$ & 0,10 & 1 & 0,10 & $\begin{array}{l}\text { Akam mampengaruhi } \\
\text { perkembangan kedepannya }\end{array}$ \\
\hline & Total Score & 1 & & 2,35 & \\
\hline
\end{tabular}

http://ejurnal.binawakya.or.id/index.php/MBI

Open Journal Systems 
Tabel 2. Analisis Faktor Strategis Faktor Eksternal (EFAS) Sektor Pariwisata

\begin{tabular}{|c|c|c|c|c|c|}
\hline No & Faltor-faltor strategis & Bobot & Ranting & Score & Komentar \\
\hline \multirow[t]{4}{*}{ I } & Peluang & & & & \\
\hline & $\begin{array}{l}\text { a. Masyrakat luar sudah } \\
\text { mulai mengenal Lombok } \\
\text { Timur Sebagai salah satu } \\
\text { destinasi wisata favorit }\end{array}$ & 0,20 & 3 & 0,60 & Akuisisi \\
\hline & $\begin{array}{l}\text { b. sudah mulai gaungaya } \\
\text { Lombok sebagai destinasi } \\
\text { wisata halal }\end{array}$ & 0,10 & 3 & 0,30 & $\begin{array}{c}\text { Keberadaan } \\
\text { lemah }\end{array}$ \\
\hline & 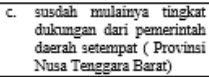 & 0,20 & 3 & 0,60 & Lemah \\
\hline \multirow[t]{3}{*}{ II } & Ancaman & & & & \\
\hline & 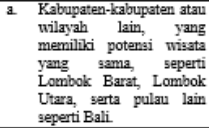 & 0,30 & 1 & 0,30 & $\begin{array}{l}\text { Perhu strategi } \\
\text { merebut pasar }\end{array}$ \\
\hline & 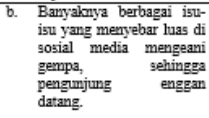 & 0,20 & 2 & 0,40 & $\begin{array}{l}\text { Perlu hati-hati } \\
\text { kama ini } \\
\text { addah } \\
\text { tantangan }\end{array}$ \\
\hline & Total Score & 1 & & 2,2 & \\
\hline
\end{tabular}

Sumber: Data Lampiran Diolah

Untuk mengetahui letak kuadran strategi yang dianggap memiliki prioritas tertinggi dan harus dilakukan guna pengembangan sektor pariwisata di Kabupaten Lombok Timur, digunakan formulasi sumbu $\mathrm{X}$ dan $\mathrm{Y}$, dimana sumbu $X$ adalah EFAS (peluang-ancaman) sedangkan sumbu Y merupakan IFAS (kekuatankelemahan) yang dinyatakan dengan nilai hasil scoring dari tabel 4 dan 5 sebagaimana hasilnya dapat digambarkan pada gambar dibawah ini :

Gambar 1: Grafik Letak Kuadran Analisis SWOT Sektor Pariwisata

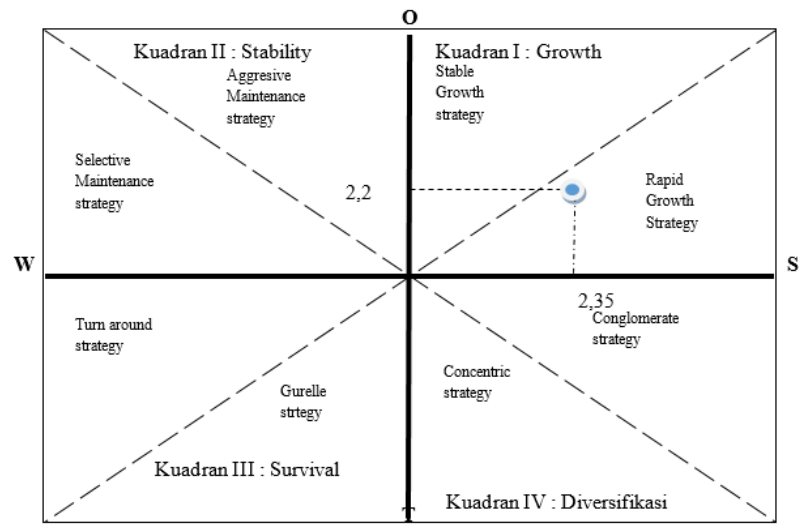

Berdasarkan formulasi letak kuadran pada gambar di atas, strategi yang harus dilaksanakan oleh pemerintah daerah Kabupaten Lombok Timur untuk memaksimalkan potensi sektor pariwisata untuk sebagai penopang atau pendongkrak pertumbuhan ekonomi di Kabupaten Lombok Timur terletak pada kuadran I atau terletak anatara peluang eksternal dan http://ejurnal.binawakya.or.id/index.php/MBI Open Journal Systems kekuatan internal yang bersifat positif (strategi pertumbuhan) dengan rapid growth strategi yaitu strategi yang wajib digunakan untuk meningkatkan dan memaksimalkan output dari sektor pariwisata ini untuk terus berkembang sehingga nantinya menjadi potensi sektor unggulan di Kabupaten Lombok Timur.

Berdasarkan kuadran di atas, strategi yang mendesak pada kuadran I termasuk pada rapid growth strategy (strategi pertumbuhan cepat) yaitu suatu strategi yang digunakan untuk memaksimalkan potensi sektor pariwisata di Kabupaten Lombok Timur, guna peningkatan pertumbuhan ekonomi di Kabupaten Lombok Timur

Berdasarkan kuadran tersebut maka berikut disusun grand starategi dalam memaksimalkan matrikk IFAS dan EFAS sektor pariwisata di Kabupaten Lombok Timur adalah sebagai berikut

Tabel 2. Matriks Analisis SWOT Sektor Pariwisata Kabupaten Lombok Timur

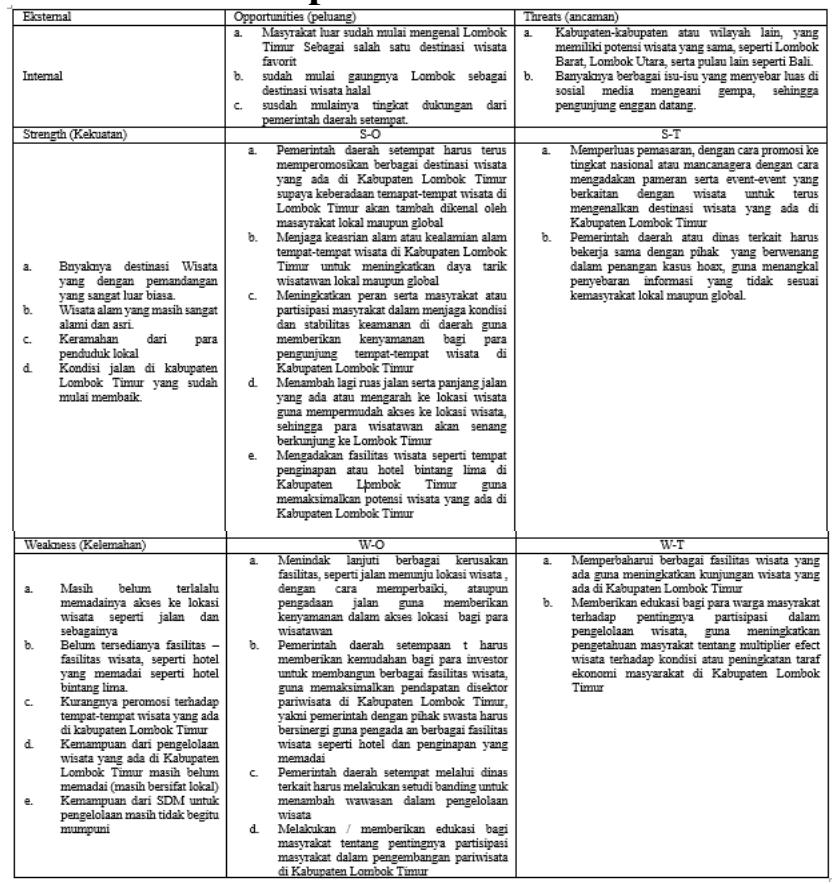

Sumber : data diolah

Berdasarkan hasil analisis IFAS dan EFAS yang tertuang dalam grafik letak kuadran maka strategi SO merupakan strategi yang dianggap memiliki prioritas yang tinggi dan mendesak untuk dilaksanakan untuk

Vol.14 No.4 Nopember 2019 
memaksimalkan potensi pariwisata di Kabupaten Lombok Timur guna peningkatan pertumbuhan ekonomi di Kabupaten Lombok Timur adalah :

a. Pemerintah daerah setempat harus terus memperomosikan berbagai destinasi wisata yang ada di Kabupaten Lombok Timur supaya keberadaan temapattempat wisata di Lombok Timur akan tambah dikenal oleh masayrakat lokal maupun global

b. Menjaga keasrian alam atau kealamian alam tempat-tempat wisata di Kabupaten Lombok Timur untuk meningkatkan daya tarik wisatawan lokal maupun global

c. Meningkatkan peran serta masyrakat atau partisipasi masyrakat dalam menjaga kondisi dan stabilitas keamanan di daerah guna memberikan kenyamanan bagi para pengunjung tempat-tempat wisata di Kabupaten Lombok Timur

d. Menambah lagi ruas jalan serta panjang jalan yang ada atau mengarah ke lokasi wisata guna mempermudah akses ke lokasi wisata, sehingga para wisatawan akan senang berkunjung ke Lombok Timur

e. Mengadakan fasilitas wisata seperti tempat penginapan atau hotel bintang lima di Kabupaten Lombok Timur guna memaksimalkan potensi wisata yang ada di Kabupaten Lombok Timur.

Pengembangan sektor pariwisata ini tidak terlepas dari peran investasi sebaga sumber dana dalam pengembangan sektor potensial ini, khususnya sektor pariwisata, untuk itu pemerintah harus bekerjasama dengan pihak investor, khususnya investor lokal dalam pengembangan pariwisata di Kabupaten Lombok Timur

\section{PENUTUP}

\section{Kesimpulan}

Kaitannya dengan hasil analisis SWOT yang dilakukan oleh peneliti maka hal yang harus ditempuh atau dilakukan oleh pemerintah daerah stempat Kabupaten Lombok Timur dalam meningkatkan peran wisata Lombok Timur yakni, pemerintah daerah harus senantiasa melakukan promosi keberbagai wilayah, yakni local maupun interlokal, guna meningkatkan jumlah kunjungan wisata di Kabupaten Lombok Timur, selain itu juga pemerintah daerah aharus terus membumingkan wisata Lombok Timur yakni dengan melakukan Expo ataupun mengadakan event-event budaya guna memperkenalkan kebudayaan serta kearifan Lombok Timur, selain itu juga pemerintah daerah harus membuka sebesar-besarnya peluang investasi bagi para investor di bidang pariwisata sehingga tercipta kemajuan di sector pariwisata di Kabupaten Lombok Timur.

\section{DAFTAR PUSTAKA}

[1] Nasiha, S. (2010). Strategi Komunikasi Pemasaran Terpadu (Integrated Marketing Communication) Dalam Mengkokohkan Brand Dagadu Djokja. Skripsi. Yogyakarta: UIN Sunan Kalijaga.

[2] Novrilasari, D. (2008). Analisis Sektor Unggulan Dalam Meningkatkan Perekonomian dan

[3] Pembangunan Wilayah Kabupaten Kuantan Singingi. Skripsi Fakultas Pertanian IPB.

[4] Suci, S. D. P. (2010). Promosi kota solo sebagai kota budaya. Studi Deskriptif Kualitatif Tentang Kegiatan Komunikasi Pemasaran Dalam Promosi Kota Solo Sebagai Kota Budaya oleh Dinas Kebudayaan dan Pariwisata). Skripsi. Surakarta: UNS.

[5] Wahono, P., Karyadi, H., Suhartono, S., Prakoso, A., Prananta, R., \& Lokaprasida, P. (2017). PROSPEK EKONOMI PENGEMBANGAN POTENSI LOKAL DALAM MENDUKUNG PENGELOLAAN WISATA DI WILAYAH SEKITAR GUNUNG BROMO. CAKRAWALA, 11(2), 195-216.

http://ejurnal.binawakya.or.id/index.php/MBI Open Journal Systems 